University of Nebraska - Lincoln

DigitalCommons@University of Nebraska - Lincoln

U.S. Environmental Protection Agency Papers

U.S. Environmental Protection Agency

2010

\title{
Habitat-Related Benthic Macrofaunal Assemblages of Bays and Estuaries of the Western United States
}

\author{
J. Ananda Ranasinghe \\ Southern California Coastal Water Research Project, AnandaR@sccwrp.org \\ Kathy I. Welch \\ Washington State Department of Ecology \\ Peter N. Slattery \\ Moss Landing Marine Laboratories \\ David E. Montagne \\ David D. Huff \\ University of Minnesota \\ See next page for additional authors
}

Follow this and additional works at: https://digitalcommons.unl.edu/usepapapers

Ranasinghe, J. Ananda; Welch, Kathy I.; Slattery, Peter N.; Montagne, David E.; Huff, David D.; Lee, Henry II; Hyland, Jeffrey L.; Thompson, Bruce; Weisberg, Stephen B.; Oakden, James M.; Caiden, Donald B.; and Velarde, Ronald G., "Habitat-Related Benthic Macrofaunal Assemblages of Bays and Estuaries of the Western United States" (2010). U.S. Environmental Protection Agency Papers. 149.

https://digitalcommons.unl.edu/usepapapers/149

This Article is brought to you for free and open access by the U.S. Environmental Protection Agency at DigitalCommons@University of Nebraska - Lincoln. It has been accepted for inclusion in U.S. Environmental Protection Agency Papers by an authorized administrator of DigitalCommons@University of Nebraska - Lincoln. 


\section{Authors}

J. Ananda Ranasinghe, Kathy I. Welch, Peter N. Slattery, David E. Montagne, David D. Huff, Henry Lee II, Jeffrey L. Hyland, Bruce Thompson, Stephen B. Weisberg, James M. Oakden, Donald B. Caiden, and Ronald G. Velarde 


\title{
Habitat-Related Benthic Macrofaunal Assemblages of Bays and Estuaries of the Western United States
}

\author{
J Ananda Ranasinghe, ${ }^{*} \dagger$ Kathy I Welch, $\ddagger$ Peter N Slattery, §David E Montagne, || David D Huff,\# Henry Lee II, $\dagger \dagger$ \\ Jeffrey L Hyland, $\ddagger \ddagger$ Bruce Thompson, $\S \S$ Stephen B Weisberg, $\dagger$ James M Oakden, $\S$ Donald B Cadien, /II and \\ Ronald G Velarde\#\# \\ †Southern California Coastal Water Research Project, 3535 Harbor Blvd., Suite 110, Costa Mesa, California 92626, USA \\ $\ddagger$ Washington State Department of Ecology, Olympia, Washington, USA \\ §Benthic Laboratory, Moss Landing Marine Laboratories, Moss Landing, California, USA \\ "Penn Valley, California, USA \\ \#Department of Fisheries, Wildlife, and Conservation Biology, University of Minnesota, St. Paul, Minnesota, USA \\ t†US Environmental Protection Agency, Western Ecology Division, Newport, Oregon, USA \\ $\ddagger \ddagger$ National Oceanic and Atmospheric Administration (NOAA), Center for Coastal Environmental Health and Biomolecular Research, \\ Charleston, South Carolina, USA \\ $\S \S S a n$ Francisco Estuary Institute, Oakland, California, USA \\ ||||Sanitation Districts of Los Angeles County, P.O. Box 4998, Whittier, California 90607, USA \\ \#\#City of San Diego, Marine Biology Laboratory, San Diego, California, USA
}

(Submitted 4 June 2009; Returned for Revision 17 November 2009; Accepted 29 December 2009)

\section{Editor's Note}

This article represents 1 of 6 papers describing development and evaluation of a sediment quality assessment framework to support implementation of California's new sediment quality objectives for bays and estuaries, which became effective in 2009. Over thirty scientists collaborated on this effort by the California State Water Resources Control Board, which resulted in the establishment of one of the first statewide programs in the US to fully incorporate the sediment quality triad for regulatory applications.

\begin{abstract}
Data from 7 coastwide and regional benthic surveys were combined and used to assess the number and distribution of estuarine benthic macrofaunal assemblages of the western United States. Q-mode cluster analysis was applied to 714 samples and site groupings were tested for differences in 4 habitat factors (latitude, salinity, sediment grain size, and depth). Eight macrofaunal assemblages, structured primarily by latitude, salinity, and sediment grain size, were identified: (A) Puget Sound fine sediment, (B) Puget Sound coarse sediment, (C) southern California marine bays, (D) polyhaline central San Francisco Bay, (E) shallow estuaries and wetlands, (F) saline very coarse sediment, (G) mesohaline San Francisco Bay, and (H) limnetic and oligohaline. The Puget Sound, southern California, and San Francisco Bay assemblages were geographically distinct, while Assemblages $\mathrm{E}, \mathrm{F}$ and $\mathrm{H}$ were distributed widely along the entire coast. A second Q-mode cluster analysis was conducted after adding replicate samples that were available from some of the sites and temporal replicates that were available for sites that were sampled in successive years. Variabilities due to small spatial scale habitat heterogeneity and temporal change were both low in Puget Sound, but temporal variability was high in the San Francisco estuary where large fluctuations in freshwater inputs and salinity among years leads to spatial relocation of the assemblages. Integr Environ Assess Manag 2012;8:638-648. (c) 2010 SETAC
\end{abstract}

Keywords: Habitat-related benthic assemblages US west coast bays estuaries

\section{INTRODUCTION}

Although individual species are typically distributed in complex ways along environmental gradients, the combined result is often a series of identifiable assemblages that partition available habitat along gradients of a few variables (Boesch 1973, 1977; Orloci 1975; Whittaker 1978; Smith et al. 1988; Thompson et al. 2000; Bergen et al. 2001; Llansó et al. 2002; Hyland et al. 2004). Identification of assemblages

* To whom correspondence may be addressed: anandar@sccwrp.org Published on the Web 1 February 2010. Subsequently, the final two numbers in the "Total" column of Table 1 were incorrect, and the correction was published on 31 March 2011

DOI: $10.1002 /$ ieam.62 along habitat gradients has recently taken on an applied significance, as biocriteria have become a central focus of ecological assessments in the United States (USEPA 1991; Jackson and Davis 1994; Gibson et al. 2000). Similar measures are being developed in Europe under the Water Framework Directive (EC 2000). Biocriteria require definitions of reference conditions, which typically vary among habitats because species composition and abundances also differ naturally between habitats (Weisberg et al. 1997; Van Dolah et al. 1999). Therefore, determining the habitat variables that are most important in structuring biological assemblages and identifying the threshold values of these variables that result in natural breaks in biological assemblages are necessary components of defining reference conditions (Hughes et al. 1986; Bald et al. 2005). Information on the state of ecosystem condition contributes to the baseline 
needed for implementation of ecosystem based management (EBM), a rapidly evolving paradigm for managing coastal resources in the United States and elsewhere (UNESCO 2006; Murawski 2007).

Although benthic macrofauna have long been used as indicators of human impacts in marine environments, macrobenthic assemblages of the western United States bays and estuaries are poorly described, at least from a coastwide perspective. There have been previous regional studies of benthic assemblages in Puget Sound (Llansó et al. 1998) and San Francisco Bay (Thompson et al. 2000), but there are substantial data gaps along the $12654 \mathrm{~km}$ of western US shoreline (NOAA 1975) that have prevented a coastwide estuarine assessment. In addition, combining data from the regional studies has been difficult because of differences in the types of sampling gear and sieve mesh sizes that were used.

The US Environmental Protection Agency's (USEPA) Coastal 2000 initiative led to a west coastwide benthic sampling effort with compatible sampling designs and collection methods. Here we use those data, in combination with data from several regional programs that were collected using similar methods, to: (a) identify the benthic assemblages that occur naturally in bays and estuaries of the western USA, and (b) identify the habitat factors that are associated with assemblage differences. Additional data from programs that collected replicates in space and time were used to evaluate the effects of small spatial scale heterogeneity and interannual variability on assemblage similarity.

\section{METHODS}

We used hierarchical cluster analysis of macrobenthic species abundance data to identify the benthic assemblages that occur naturally in bays and estuaries of the western USA and the habitat factors that structure them. These analyses were based on 1086 benthic samples from 7 coastwide and regional projects with similar sampling regimes conducted between 1994 and 2003 (Table 1). All but 1 included probability-based sampling designs, so that all subtidal bay and estuary areas had known chances of inclusion.

All samples were collected with a $0.1 \mathrm{~m}^{2}$ Van Veen grab, except in San Francisco Bay, where data from two $0.05 \mathrm{~m}^{2}$ Van Veen grabs at each station were combined. Samples with a penetration depth of at least $5 \mathrm{~cm}$ and no evidence of postsampling disturbance (i.e., washing or slumping) were sieved through 1-mm mesh screens. Sieve contents were placed in a relaxant for $30 \mathrm{~min}$ and then preserved in 10\% sodium borate buffered formalin. Samples were rinsed and transferred from formalin to $70 \%$ ethanol after approximately 1 week. Specimens were then identified to the lowest practical taxon, most often species, and enumerated. Taxonomic inconsistencies among projects were eliminated by cross-correlating the species lists, identifying differences in nomenclature, and resolving discrepancies by consulting project taxonomists. Taxonomic nomenclature for provisional taxa (e.g., Cossura sp A) followed SCAMIT Edition 4 (Southern California Association of Marine Invertebrate Taxonomists 2001).

Habitat data collected with each sample included depth, bottom water salinity and dissolved oxygen concentration measurements. Sediments from the top $2 \mathrm{~cm}$ of additional grab samples were analyzed for grain size distribution, contaminant concentrations (trace metals, dichloro-diphenyl-trichloroethane (DDT), polychlorinated biphenyls (PCBs), and polycyclic aromatic hydrocarbons (PAHs)), total organic carbon

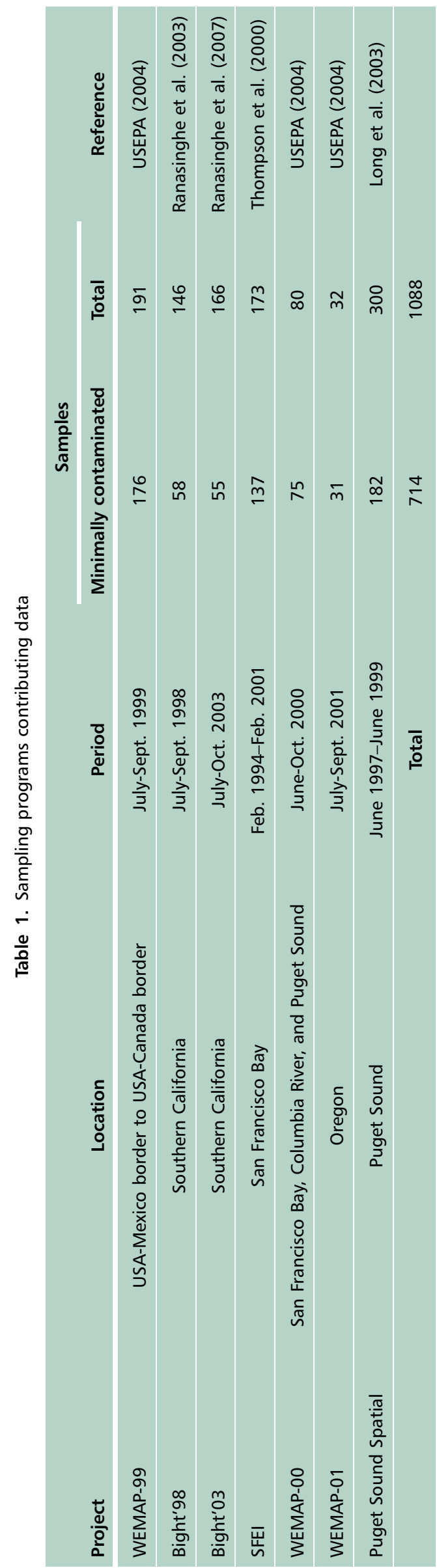


(TOC), and acute toxicity to amphipods using standard methods (Schiff 2000; Long et al. 2003; Schiff et al. 2006). All data were evaluated for methodological consistency and normalized for units of measure.

As our objective was to define natural groupings of samples with similar species composition, potentially polluted sites were eliminated before analysis. The criteria for eliminating a site as potentially polluted followed from those of Bergen et al. (2001): 1) more than 3 chemicals exceeded Long et al. (1995) effects range low (ERL) values, 2) 1 or more chemicals exceeded Long et al. (1995) effects range median (ERM) values, 3) bottom dissolved oxygen was $<2 \mathrm{ppm}, 4$ ) amphipod survival in 10-day acute toxicity tests was $<50 \%$, or 5) the site was located within $3 \mathrm{~km}$ of a known highly contaminated area or a storm water or municipal wastewater outfall. Ni and DDT were not included in the exclusion criteria because the ERM and ERL values for these chemicals are known to be poor predictors of biological responses (Long et al. 1995; Vidal and Bay 2005). After eliminating potentially contaminated sites, data from 714 samples remained for analysis (Table 1).

Groups of samples with similar species composition were identified by cluster analysis and the groups were tested for habitat differentiation using nonparametric statistical methods. Q-mode cluster analyses were conducted using flexible sorting of Bray-Curtis dissimilarity values with $\beta=-0.25$ (Bray and Curtis 1957; Lance and Williams 1967; Clifford and Stephenson 1975). Before analysis, the influence of dominant species was reduced by cube-root transformation of species abundances and nodal analysis (2-way table) interpretation was facilitated by standardization of abundances by the species mean across all samples for abundance values higher than zero (Smith 1976; Smith et al. 1988). The step-across distance reestimation procedure (Williamson 1978; Bradfield and Kenkel 1987) was applied to dissimilarity values higher than 0.80 to reduce the distortion of ecological distances caused by joint absences of a high proportion of species; distortion occurs due to the nonmonotonic truncated joint species distribution. Before cluster analysis, species occurring only at 1 site were eliminated.

Habitat-related assemblages were identified by sequentially examining splits in the cluster analysis dendrogram, starting with the first split and proceeding along branches, to assess whether each split reflected habitat differentiation. Habitat differentiation was defined as: (1) a significant $(p<0.05)$ Mann-Whitney-Wilcoxon difference in median for any of 4 habitat variables (bottom salinity, bottom depth, percent fine $(<63 \mu$ grain size) sediments, and latitude) between the 2 sample groupings defined by the dendrogram split, and (2) accurate segregation of more than $90 \%$ of the samples in the split according to criteria based on significant habitat variables. Probabilities were not adjusted to account for multiple testing because we were only interested in controlling the comparisonwise error rate.

For each habitat-related assemblage, abundant and characteristic taxa were identified as those with a mean assemblage abundance $>10$ per $0.1 \mathrm{~m}^{2}$ sample and fidelity $>50 \%$ or exclusivity $>80 \%$. Fidelity was calculated as the frequency of occurrence of a taxon in assemblage samples, expressed as a percentage. Exclusivity was the abundance of a taxon in assemblage samples, expressed as a percentage of its total abundance in all samples.

A second cluster analysis was used to evaluate the effects of small spatial scale heterogeneity and interannual variability on assemblage fidelity. In this analysis, data used in the first analysis were supplemented by triplicate samples from 10 Puget Sound sites that were collected each year from 1997 to 2002 and San Francisco Bay temporal replicates that were sampled 10-13 times from 1994 to 2001. The sampling and laboratory methods for benthic species abundance and habitat data, and the cluster analysis details, were the same as for the first analysis. The relative magnitude of small spatial scale assemblage variability and stability over time were evaluated by measuring the percentage of samples from a site that occurred next to each other in the dendrogram.

\section{RESULTS}

Sequential analysis of the spatial dendrogram yielded 8 habitat-related benthic macrofaunal assemblages in western US bays and estuaries (Figure 1). Statistically significant $(p>0.05)$ differences existed for bottom water salinity, bottom depth, percent fines, or latitude across each of the 7 dendrogram splits labeled in Figure 1 (Table 2). Split 1 and Split 7 were significantly different for all 4 habitat variables, while Splits 2, 3, 4, and 5 were significantly different for 3 . Split 6 was significant only for salinity and percent fines. Medians for latitude and percent fines were significantly

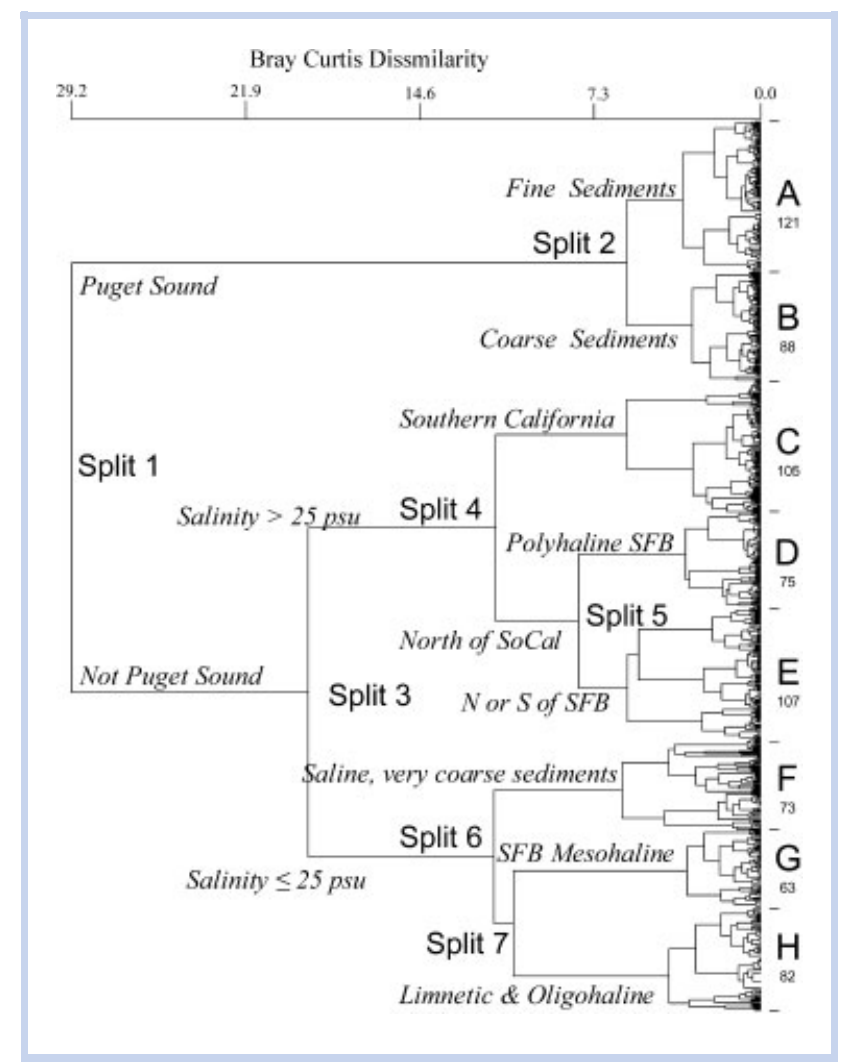

Figure 1. Dendrogram showing the habitat-related assemblages $(A-H)$ identified by cluster analysis. (A) Puget Sound fine sediment assemblage; (B) Puget Sound coarse sediment assemblage; (C) Southern California marine bay assemblage; (D) Polyhaline San Francisco Bay assemblage; (E) Estuaries and wetlands assemblage; (F) Saline very coarse sediment assemblage; (G) Mesohaline San Francisco Bay assemblage; $(\mathrm{H})$ Limnetic and oligohaline (tidal freshwater) assemblage. The number of samples for each assemblage is presented under the assemblage letter. Splits 1-7 identify dendrogram branch points referred to in the text and tables. Habitat factors separating samples across splits are summarized in italicized text. SFB: San Francisco Bay; $\mathrm{N}$ : North; S: South. 
Table 2. Ranges of values for salinity, depth, percent fines, and latitude for samples across splits in the spatial dendrogram (Figure 1). Underlined numbers indicate significant $(p<0.05)$ differences in median across the dendrogram splits that were identified by MannWhitney-Wilcoxon tests

\begin{tabular}{|c|c|c|c|c|c|c|}
\hline Split & Assemblage & $\mathbf{N}$ & Salinity (psu) & Depth (m) & Fines $(\%)$ & Latitude (Decimal degrees) \\
\hline \multirow[t]{2}{*}{1} & $A B$ & 209 & $\underline{25.7-33.0}$ & $\underline{2.1-250}$ & $\underline{0.0-99.6}$ & $38.0023-48.9950$ \\
\hline & CDEFGH & 505 & $\underline{0.0-39.4}$ & $\underline{0.0-26.7}$ & $\underline{0.0-100}$ & $\underline{32.5568-48.3137}$ \\
\hline \multirow[t]{2}{*}{2} & $A$ & 121 & $28.5-33.0$ & $\underline{2.4-250}$ & $\underline{13.5-99.6}$ & 47.0575-48.9950 \\
\hline & B & 88 & $25.7-32.5$ & $\underline{2.1-213}$ & $\underline{0.0-93.7}$ & $\underline{38.0023-48.9842}$ \\
\hline \multirow[t]{2}{*}{3} & $\mathrm{CDE}$ & 287 & $3.8-39.4$ & $0.0-23.0$ & $\underline{1.2-100}$ & $\underline{32.6213-47.0053}$ \\
\hline & FGH & 218 & $\underline{0.0-38.0}$ & $0.4-26.7$ & $\underline{0.0-99.7}$ & $\underline{32.5568-48.3137}$ \\
\hline \multirow[t]{2}{*}{4} & C & 105 & $\underline{27.2-39.4}$ & $\underline{0.4-23.0}$ & $2.8-100$ & $\underline{32.6213-34.1801}$ \\
\hline & DE & 182 & $3.8-34.0$ & $\underline{0.0-16.0}$ & $1.2-99.5$ & $32.7585-47.0053$ \\
\hline \multirow[t]{2}{*}{5} & D & 75 & $9.7-34.0$ & $1.0-16.0$ & $\underline{3.5-99.5}$ & $\underline{37.5591-46.9665}$ \\
\hline & $\mathrm{E}$ & 107 & $3.8-34.0$ & $0.0-13.8$ & $1.2-99.4$ & $32.7585-47.0053$ \\
\hline \multirow[t]{2}{*}{6} & $\mathrm{~F}$ & 73 & $\underline{0.1-33.2}$ & $0.4-26.5$ & $\underline{0.0-63.0}$ & $32.5568-48.3137$ \\
\hline & $\mathrm{GH}$ & 145 & $\underline{0.0-38.0}$ & $0.5-26.7$ & $\underline{0.0-99.7}$ & $34.0326-46.3017$ \\
\hline \multirow[t]{2}{*}{7} & G & 63 & $\underline{0.0-38.0}$ & $\underline{0.7-12.0}$ & $\underline{0.0-99.7}$ & $\underline{37.4928-38.2089}$ \\
\hline & $\mathrm{H}$ & 82 & $0.0-32.0$ & $0.5-26.7$ & $0.0-97.2$ & $34.0326-46.3017$ \\
\hline
\end{tabular}

different across 6 of the 7 splits, while medians for salinity and depth were significant across 5 splits.

The habitat criteria classified samples across splits with greater than $90 \%$ accuracy for 5 of the 7 splits in the species abundance dendrogram (Table 3). Classification accuracy was $>98 \%$ for 2 splits. The splits with less than 90\% accuracy separated heterogeneous branches with multiple assemblages that separated with higher accuracy in subsequent splits. The lowest accuracy of $76.8 \%$ was for Split 3, where each branch included 3 assemblages that separated with accuracy $>94 \%$ in subsequent splits.

Although there were assemblage differences associated with all 4 habitat variables (Figure 2), habitat criteria separating samples across splits were associated primarily with differences in latitude, bottom water salinity, and sediment composition (Table 3). Latitude was included in the habitat criteria for separating assemblages across 4 of the 7 splits, while bottom water salinity and sediment type were each included for 2 splits. Bottom depth was included only in 1 criterion, and even then only as a modifier of sediment type under limited circumstances.

The 2 assemblages including all the Puget Sound benthos were distinct from the other 6 western bay and estuarine benthic assemblages, separating from them at the first dendrogram branch (Split 1 in Figure 1, Table 3). The Puget Sound benthos then separated at Split 2 into 2 assemblages that were distinguished by a combination of sediment type and bottom depth. Although Assemblage A, the Puget Sound fine sediment assemblage, and Assemblage B, the Puget Sound coarse sediment assemblage, separated well at depths greater than $40 \mathrm{~m}$, the 2 assemblages commingled at lesser depths (Figure 3).

The 6 benthic assemblages from outside Puget Sound split first on salinity criteria (Table 3) although differences in numbers of taxa were the most likely biological factor. Assemblages C, D, and E, with, on average, 43.3, 24.5, and 15.9 taxa per sample, respectively, separated from Assemblages $F, G$, and $H$, which had $8.9,5.4$, and 5.0 taxa per sample, respectively (Table 4). Assemblage $\mathrm{F}$, which included benthos from mesohaline and higher salinity habitats with very coarse sediments, grouped with the other low diversity assemblages from limnetic, oligohaline, and mesohaline habitats rather than higher salinity Assemblages C, D, and E.

Subsequent dendrogram splits in the non-Puget Sound benthos were clearly related to geographic and habitat factors. The higher diversity branch split into the southern California marine bays (Assemblage C), the polyhaline central San Francisco Bay (Assemblage D), and the geographically widespread shallow estuaries and wetland Assemblage E (Figure 1). The low diversity branch split into the saline habitats with very coarse sediments (Assemblage F), the mesohaline San Francisco Bay Assemblage G, and the geographically widespread limnetic and oligohaline Assemblage $\mathrm{H}$.

Five of the assemblages included samples from narrow geographic distributions. These included the Puget Sound fine and coarse sediment assemblages (Assemblages A and B), the southern California marine bay assemblage (C), and the San Francisco Bay polyhaline (D) and mesohaline (G) assemblages (Figure 2B). The other 3 assemblages had broad geographic distributions and included the shallow estuaries and wetland Assemblage E, mesohaline and higher salinity habitats with very coarse sediments (Assemblage F), and limnetic and oligohaline Assemblage $\mathrm{H}$.

Different macrobenthic taxa were characteristic of the 8 assemblages (Table 5). More than half the abundant and characteristic taxa in each assemblage had high exclusivity, with $>80 \%$ of the abundance of those taxa occurring in that 
Table 3. Habitat classification accuracy for samples across splits in the spatial dendrogram

\begin{tabular}{|c|c|c|c|c|c|}
\hline Split & Assemblage & Description & $\mathbf{N}$ & Habitat Criteria & Accuracy (\%) \\
\hline \multirow[t]{2}{*}{1} & $A B$ & Puget Sound & 209 & $\begin{array}{l}\text { Latitude }>47^{\circ} \mathrm{N} \text { and } \\
\text { Longitude }<123.5^{\circ} \mathrm{W}\end{array}$ & 98.9 \\
\hline & CDEFGH & Not Puget Sound & 505 & $\begin{array}{l}\text { Latitude } \leq 47^{\circ} \mathrm{N} \text { and } \\
\text { Longitude } \geq 123.5^{\circ} \mathrm{W}\end{array}$ & \\
\hline \multirow[t]{2}{*}{2} & A & Puget Sound fine sediments & 121 & Fines $>45 \%$ or Fines $>45-$ Depth $* 0.75$ & 91.9 \\
\hline & B & Puget Sound coarse sediments & 88 & Fines $<15 \%$ or Fines $<45-$ Depth 0.75 & \\
\hline \multirow[t]{2}{*}{3} & $\mathrm{CDE}$ & High salinity & 287 & Salinity $>25.0 \mathrm{psu}$ & 76.8 \\
\hline & FGH & Low salinity & 218 & Salinity $\leq 25.0$ psu & \\
\hline \multirow[t]{2}{*}{4} & $\mathrm{C}$ & Southern California & 105 & Latitude $<34.5^{\circ} \mathrm{N}$ & 94.1 \\
\hline & $\mathrm{DE}$ & North of southern California & 182 & Latitude $\geq 34.5^{\circ} \mathrm{N}$ & \\
\hline \multirow[t]{2}{*}{5} & D & $\begin{array}{l}\text { San Francisco Bay Polyhaline } \\
\text { assemblage }\end{array}$ & 75 & Latitude $>37.5^{\circ} \mathrm{N}$ and $<38.0^{\circ} \mathrm{N}$ & 94.5 \\
\hline & $\mathrm{E}$ & North or south of San Francisco Bay & 107 & Latitude $\leq 37.5^{\circ} \mathrm{N}$ or $\geq 38.0^{\circ} \mathrm{N}$ & \\
\hline \multirow[t]{2}{*}{6} & $\mathrm{~F}$ & $\begin{array}{l}\text { Very coarse sediments in mesohaline } \\
\text { and higher salinity habitats }\end{array}$ & 73 & Salinity $>5$ psu and Fines $\leq 7.5 \%$ & 87.6 \\
\hline & GH & $\begin{array}{l}\text { Limnetic \& oligohaline salinities, and } \\
\text { mesohaline samples with fine } \\
\text { sediments }\end{array}$ & 145 & Salinity $\leq 5$ psu or Fines $>7.5 \%$ & \\
\hline \multirow[t]{2}{*}{7} & G & $\begin{array}{l}\text { San Francisco Bay mesohaline } \\
\text { assemblages }\end{array}$ & 63 & Latitude $37.0^{\circ} \mathrm{N}-38.5^{\circ} \mathrm{N}$ & 98.6 \\
\hline & $\mathrm{H}$ & $\begin{array}{l}\text { Limnetic and oligohaline assem- } \\
\text { blages elsewhere }\end{array}$ & 82 & Latitude $<37.0^{\circ} \mathrm{N}$ or $>38.5^{\circ} \mathrm{N}$ & \\
\hline
\end{tabular}

assemblage alone. Only 4 of 69 characteristic taxa were abundant in more than 1 assemblage, including the capitellid polychaete Mediomastus spp. and annelids of the Class Oligochaeta. Each was abundant and characteristic in 3 assemblages. Mediomastus spp. occurred in $45 \%$ or more of the samples in 5 of the 6 higher salinity assemblages (Assemblages A-E) and 22\% of the samples of the sixth (Assemblage F). The taxon includes 2 species, M. californiensis and $M$. ambiseta, which have similar habitat distributions and are distinguishable only by setae on posterior segments that often break off as fragments during sample processing. The apparent broad distribution is likely true for both species, rather than an artifact due to uncertainty of species identity. Oligochaetes occurred in $>30 \%$ of the samples in 7 of the 8 habitats and in 18\% of the samples in the other (Assemblage F), and were not identified further. The broad oligochaete distribution likely reflects a combination of Tubificoides spp. at mesohaline and higher salinities with a broad diversity of oligochaetes in limnetic and oligohaline salinities (Brinkhurst 1982; Llansó et al. 2002). The ostracod Euphilomedes carcharodonta and the syllid polychaete Exogone lourei were each characteristic of 2 assemblages and were abundant and occurred frequently in a third. E. carcharodonta was characteristic of Assemblages B and C and also occurred at abundance in $31 \%$ of the Assemblage A samples. E. lourei was characteristic of Assemblages $\mathrm{C}$ and $\mathrm{D}$ and occurred at abundance in $36 \%$ of the Assemblage B samples.

In the second cluster analysis, samples from stations in the supplementary Puget Sound data clustered together on the dendrogram, forming a single group together with the Puget Sound stations that were separated from all the other samples by the first split in the dendrogram. For 9 of the 10 supplementary stations, all samples clustered together (Table 6). For the tenth station, 17 of 18 samples clustered together, with the eighteenth sample separated by 26 stations in the dendrogram. In contrast, only approximately $50 \%$ of the San Francisco Bay samples clustered adjacent to their temporal replicates. All the temporal replicates clustered together at Station BC21 in Horseshoe Bay, which is located near the mouth of San Francisco Bay and presumably under the stabilizing influence of the Pacific Ocean. In contrast, only $40-50 \%$ of the temporal replicates clustered together at the other 4 stations, which are located away from the bay mouth and more strongly influenced by freshwater flows (Thompson et al. 2000).

\section{DISCUSSION}

The results of our analysis are consistent with those of other macrobenthic assemblage analyses, indicating that latitude, salinity, and sediment grain size are among the primary determinants structuring assemblages over broad geographic areas with large latitudinal gradients (Van Dolah et al. 1999; Bergen et al. 2001; Llansó et al. 2002; Hyland et al. 2004). Our polyhaline and mesohaline San Francisco Bay assemblages are essentially the same as the marine and estuarine assemblages of Thompson et al. (2000), and our Puget Sound assemblages are similar to those of Llansó et al. (1998). We also observed the same faunal break at Point Conception that Briggs $(1974,1995)$ and Cross and Allen 


\section{A}

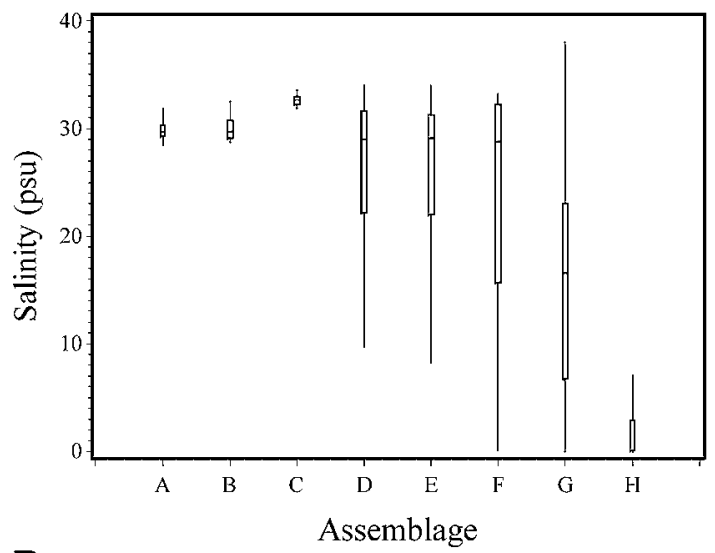

B

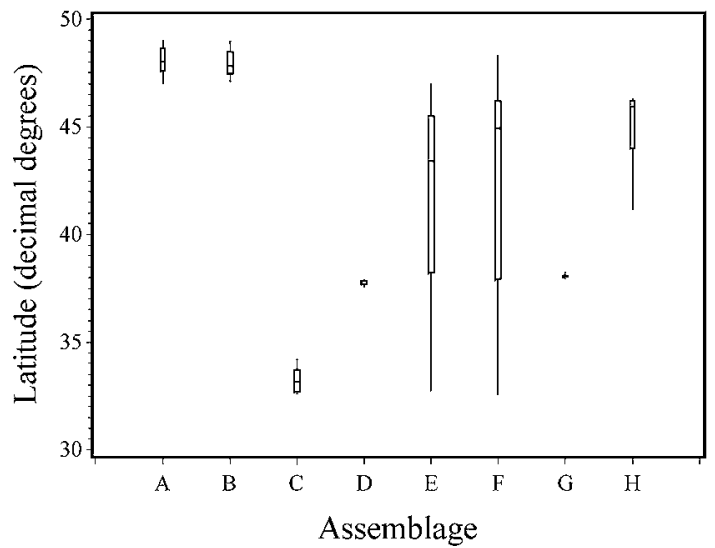

C

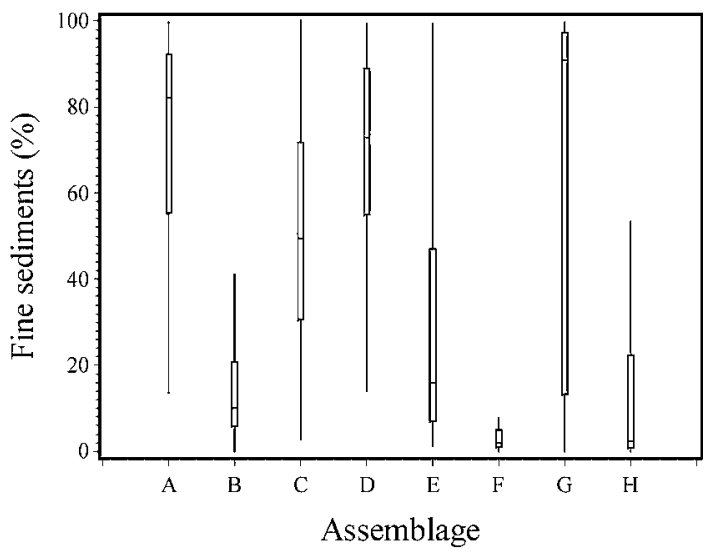

D

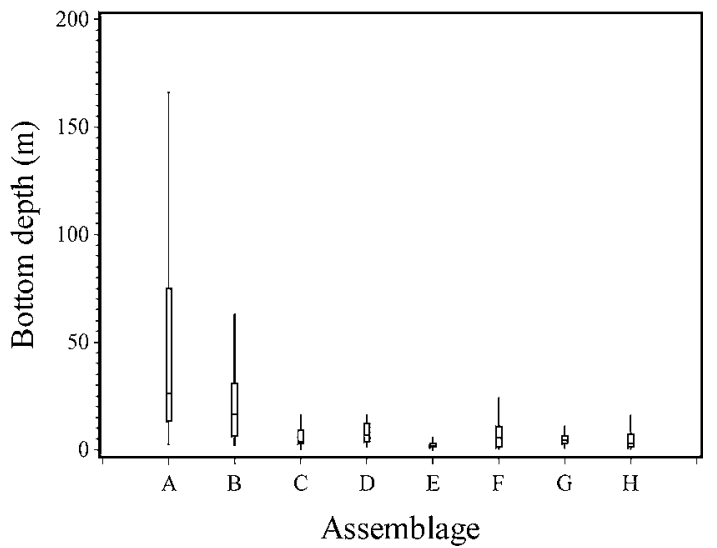

Figure 2. Box and whisker plots of habitat variables for each assemblage. (A) Salinity. (B) Latitude. (C) Sediment grain size (\% fines). (D) Water depth. Boxes indicate quartiles and medians. Whiskers join the box to the most extreme point within 1.5 interquartile ranges.

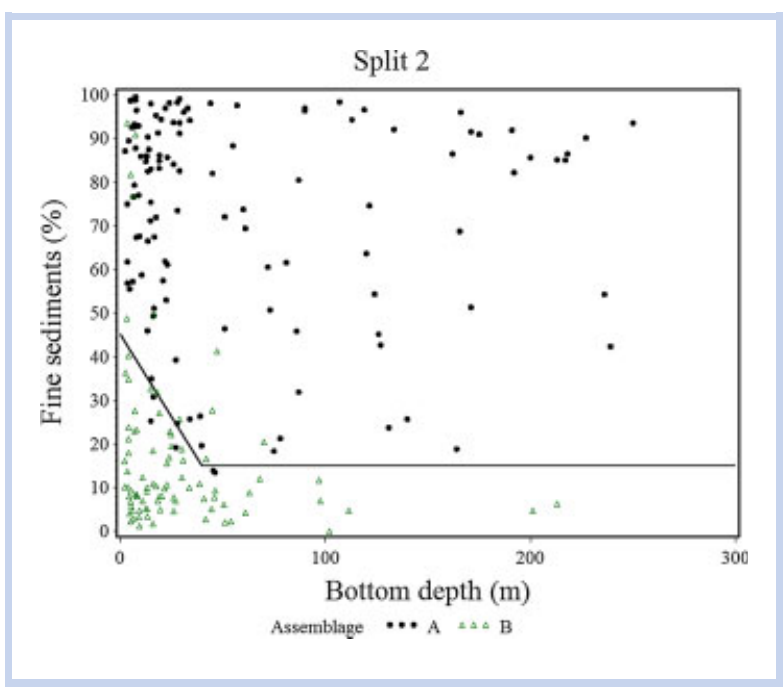

Figure 3. Distribution of assemblages across dendrogram Split 2 (see Figure 1) relative to depth and sediment type. Black dots indicate samples from Assemblage A, the Puget Sound Fine Sediments Assemblage, while open green triangles indicate samples from Assemblage B, the Puget Sound Coarse Sediments Assemblage.
(1993) observed for gastropod and marine fish species. However, we did not observe the Cape Mendocino faunal break described for gastropods by Briggs (1974, 1995). Gastropods are mostly broadcast spawners with pelagic larvae that are strongly influenced by ocean currents, whereas many benthic infaunal taxonomic groups brood their young and are less influenced by currents.

Latitude was the dominant physical factor differentiating habitats across 4 of the 7 dendrogram splits (Table 3), but the effect of salinity is probably understated because of confounding between latitude and salinity. For instance, the mesohaline San Francisco Bay assemblage was geographically restricted, but San Pablo and Suisun Bays in the San Francisco Bay estuary are the only extensive mesohaline salinity habitats on the west coast. Similarly, the paucity of rainfall in southern California creates a high salinity environment that predominates in that area. Further evidence for the importance of salinity as a structuring factor is the difference in assemblage stability between the temporal replicates in Puget Sound and those in San Francisco Bay. Puget Sound has a relatively stable salinity regime that is reflective of the consistently high rainfall of the region. In contrast, rainfall in the San Francisco estuary watershed is episodic and large intrabasin transfers for 
Table 4. Species richness and abundance (mean $\pm \mathrm{SE}$ ) for each assemblage

\begin{tabular}{|c|c|c|c|c|c|}
\hline \multirow[b]{2}{*}{ Assemblage } & \multirow[b]{2}{*}{ Habitat-Related Assemblage Description } & \multirow[b]{2}{*}{ Samples } & \multicolumn{2}{|c|}{ No. of taxa } & \multirow{2}{*}{$\begin{array}{c}\text { Total abundance } \\
\left(0.1 \mathrm{~m}^{-2}\right)\end{array}$} \\
\hline & & & Overall & Mean $\left(0.1 \mathrm{~m}^{-2}\right)$ & \\
\hline A & Puget Sound fine sediments & 121 & 410 & $42.2 \pm 1.5$ & $601.3 \pm 57.3$ \\
\hline B & Puget Sound coarse sediments & 88 & 628 & $69.2 \pm 2.4$ & $865.1 \pm 112.8$ \\
\hline C & Southern California marine bays & 105 & 501 & $43.3 \pm 1.7$ & $835.0 \pm 80.1$ \\
\hline D & Polyhaline central San Francisco Bay & 75 & 235 & $24.5 \pm 1.3$ & $1768.0 \pm 324.9$ \\
\hline$E$ & Estuaries and wetlands & 107 & 268 & $15.9 \pm 0.8$ & $2260.9 \pm 534.0$ \\
\hline $\mathrm{F}$ & Saline very coarse sediments & 73 & 181 & $8.9 \pm 0.8$ & $84.7 \pm 12.7$ \\
\hline G & Mesohaline San Francisco Bay & 63 & 60 & $5.4 \pm 0.4$ & $791.0 \pm 204.1$ \\
\hline $\mathrm{H}$ & Limnetic and oligohaline & 82 & 75 & $5.0 \pm 0.4$ & $404.7 \pm 66.7$ \\
\hline
\end{tabular}

agriculture and drinking water exacerbate salinity fluctuations (Cloern and Nichols 1985; Conomos et al. 1985). The assemblages apparently are responding to salinity conditions at sites, rather than the geographic position of sites within the estuary; species dominating limnetic and oligohaline assemblages move downstream in response to seasonal freshwater outflows and move upstream during dry weather (Nichols and Thompson 1985).

We found that substrate was of lesser importance for differentiating assemblages in lower salinities than it was in higher salinities, consistent with the findings of Weisberg et al. (1997). Sediment grain-size differences, on the other hand, differentiated the saline very coarse sediment assemblage fauna from the fauna of other habitats, and the Puget Sound fine and coarse sediment assemblages. Sediment differences may also play a role, together with salinity and bottom depth, in differentiating the estuarine and wetland assemblages which live at shallower depths (Figure 2D) than other assemblages. Bottom depth was important only as a modifier of sediment grain-size differences in shallow areas of Puget Sound (Figure 3). The lack of a strong depth influence on assemblage separation is most likely due to the relatively narrow depth range of stations outside Puget Sound; 95\% of the samples for Assemblages C-H occurred at depths $<15 \mathrm{~m}$.

One of the concerns regarding assemblage identification is the dependence of cluster analysis results on methodological choices. Recent benthic macrofauna clustering algorithms usually include the Bray-Curtiss similarity index and flexible sorting with $\beta=-0.25$ (Bergen et al. 2001; Clarke and Warwick 2001; Hyland et al. 2004), but the results may be affected by algorithms chosen for data transformation, data standardization, and step-across distance reestimation. To evaluate the effect of these choices, we compared assemblage classification consistency and dendrogram sequence order of samples for 6 variations of our chosen cluster analysis protocol, altering 1 choice for each variation. The variations eliminated step across distance reestimation or data standardization, or transformed abundance values by presenceabsence, fourth root, square root, or log transformations instead of a cube root transformation. Sample classifications and dendrogram sequences were consistent among the analyses. The variations classified an average of $84.6 \%$ of the samples within the contiguous groups identified as assemb- lages in the main analysis, with a minimum of $82.2 \%$ and a maximum of $89.1 \%$. For the 8 assemblages, average composition consistency ranged from $72.7 \%$ to $97.4 \%$ with a mean of $84.6 \%$. Assemblages separating along steep biological gradients rich in species and organisms (e.g., Assemblage B: Puget Sound coarse sediment assemblage) and depauperate assemblages (e.g., Assemblage F: Saline very coarse sediments; Table 4) were most affected by algorithm choices. In the species rich gradients, the method variations slid the assemblage separation points along the sample sequences in the absence of sharp biological discontinuities. Depauperate assemblage separation was more haphazard, reflecting a paucity of consistent information. Rank correlation coefficients for the sample dendrogram sequence order between the original analysis and variations ranged from 0.86 to 0.94 , averaging 0.91 . These results suggest that the physical habitat variables driving species composition result in consistent broad scale assemblage clusters regardless of the statistical method used, although outliers in susceptible assemblages may migrate between adjacent clusters.

There were large differences in species richness among the 8 assemblages we identified. The assemblages with the highest species richness were from higher, marine salinity environments in Puget Sound and southern California marine bays. The 2 lower salinity assemblages averaged only approximately 5 species per sample, whereas the higher salinity assemblages averaged as many as 69 species per sample. The low-salinity assemblages also had few characteristic species, with the bivalve Corbula amurensis and the polychaete Marenzelleria viridis the only taxa characteristic of the mesohaline San Francisco Bay assemblage. M. viridis is also common in east coast mesohaline habitats in Chesapeake Bay (Weisberg et al. 1997) and North Carolina (Hyland et al. 2004). Some of the lower species richness may have been due to the smaller size sampling gear used in the San Francisco estuary and because the freshwater Oligochaeta, Chironomidae, and Insecta were not identified to the genus or species level because of the time it takes to permanently mount individual organisms on microscope slides for identification, and also because of the marine faunal experience of the organizations conducting the sampling programs. However, lower species richness in low salinity environments is characteristic of the estuarine benthos (e.g., Boesch 1977) and is typically associated with the osmotic stress of that environment. 
Table 5. Exclusivity values for abundant (mean abundance $>100 \mathrm{~m}^{-2}$ ) taxa with fidelity $>50 \%$ or exclusivity $>80 \%$ in each assemblage. Taxonomic nomenclature for provisional taxa (e.g., Cossura sp. A) follows SCAMIT Edition 4 Southern California Association of Marine Invertebrate Taxonomists 2001

\begin{tabular}{|c|c|c|c|c|c|c|c|c|c|}
\hline \multirow[b]{2}{*}{ Taxon } & \multirow[b]{2}{*}{ Higher Taxon } & \multicolumn{8}{|c|}{ Assemblage } \\
\hline & & A & B & $\mathrm{C}$ & D & E & $\mathbf{F}$ & G & H \\
\hline Euphilomedes producta & Arthropoda: Ostracoda & 92 & & & & & & & \\
\hline Eudorella pacifica & Arthropoda: Cumacea & 91 & & & & & & & \\
\hline Axinopsida serricata & Mollusca: Bivalvia & 89 & & & & & & & \\
\hline Protomedeia articulata Complex & Arthropoda: Amphipoda & 89 & & & & & & & \\
\hline Protomedeia grandimana & Arthropoda: Amphipoda & 82 & & & & & & & \\
\hline Amphiodia spp. & Echinodermata: Ophiuroidea & 73 & & & & & & & \\
\hline Prionospio (Minuspio) lighti & Annelida: Polychaeta & 68 & & & & & & & \\
\hline Levinsenia gracilis & Annelida: Polychaeta & 47 & & & & & & & \\
\hline Ericthonius rubricornis & Arthropoda: Amphipoda & & 100 & & & & & & \\
\hline Phyllochaetopterus prolifica & Annelida: Polychaeta & & 100 & & & & & & \\
\hline Ampelisca agassizi & Arthropoda: Amphipoda & & 100 & & & & & & \\
\hline Alvania compacta & Mollusca: Gastropoda & & 94 & & & & & & \\
\hline Tellina modesta & Mollusca: Bivalvia & & 89 & & & & & & \\
\hline Rochefortia tumida & Mollusca: Bivalvia & & 84 & & & & & & \\
\hline Aphelochaeta glandaria Complex & Annelida: Polychaeta & & 81 & & & & & & \\
\hline Prionospio (Prionospio) dubia & Annelida: Polychaeta & & 71 & & & & & & \\
\hline Nutricola lordi & Mollusca: Bivalvia & & 63 & & & & & & \\
\hline Parvilucina tenuisculpta & Mollusca: Bivalvia & & 55 & & & & & & \\
\hline Euphilomedes carcharodonta & Arthropoda: Ostracoda & & 49 & 15 & & & & & \\
\hline Mediomastus spp. & Annelida: Polychaeta & & 9 & 42 & 16 & & & & \\
\hline Amphideutopus oculatus & Arthropoda: Amphipoda & & & 100 & & & & & \\
\hline Caecum californicum & Mollusca: Gastropoda & & & 100 & & & & & \\
\hline Cossura sp. A & Annelida: Polychaeta & & & 100 & & & & & \\
\hline Barleeia spp. & Mollusca: Gastropoda & & & 100 & & & & & \\
\hline Synaptotanais notabilis & Arthropoda: Tanaidacea & & & 100 & & & & & \\
\hline Scoletoma sp. C & Annelida: Polychaeta & & & 100 & & & & & \\
\hline Paracerceis sculpta & Arthropoda: Isopoda & & & 99 & & & & & \\
\hline Prionospio (Prionospio) heterobranchia & Annelida: Polychaeta & & & 99 & & & & & \\
\hline Fabricinuda limnicola & Annelida: Polychaeta & & & 99 & & & & & \\
\hline Tagelus subteres & Mollusca: Bivalvia & & & 96 & & & & & \\
\hline Pseudopolydora paucibranchiata & Annelida: Polychaeta & & & 89 & & & & & \\
\hline Musculista senhousia & Mollusca: Bivalvia & & & 87 & & & & & \\
\hline Theora lubrica & Mollusca: Bivalvia & & & 72 & & & & & \\
\hline Pista percyi & Annelida: Polychaeta & & & 65 & & & & & \\
\hline Leitoscoloplos pugettensis & Annelida: Polychaeta & & & 63 & & & & & \\
\hline
\end{tabular}


Table 5. (Continued)

\begin{tabular}{|c|c|c|c|c|c|c|c|c|c|}
\hline \multirow[b]{2}{*}{ Taxon } & \multirow[b]{2}{*}{ Higher Taxon } & \multicolumn{8}{|c|}{ Assemblage } \\
\hline & & A & B & C & D & E & $\mathbf{F}$ & G & H \\
\hline Euchone limnicola & Annelida: Polychaeta & & & 45 & & & & & \\
\hline Exogone lourei & Annelida: Polychaeta & & & 28 & 56 & & & & \\
\hline Crepidula convexa & Mollusca: Gastropoda & & & & 100 & & & & \\
\hline Sabaco elongatus & Annelida: Polychaeta & & & & 99 & & & & \\
\hline Ampelisca abdita & Arthropoda: Amphipoda & & & & 94 & & & & \\
\hline Caprella spp. & Arthropoda: Amphipoda & & & & 94 & & & & \\
\hline Sinocorophium heteroceratum & Arthropoda: Amphipoda & & & & 94 & & & & \\
\hline Molgula spp. & Chordata: Ascidiacea & & & & 92 & & & & \\
\hline Photis brevipes & Arthropoda: Amphipoda & & & & 90 & & & & \\
\hline Sphaerosyllis californiensis & Annelida: Polychaeta & & & & 87 & & & & \\
\hline Monocorophium acherusicum & Arthropoda: Amphipoda & & & & 84 & & & & \\
\hline Leptochelia dubia & Arthropoda: Tanaidacea & & & & 72 & & & & \\
\hline Oligochaeta & Annelida: Oligochaeta & & & & 8 & 60 & & & 19 \\
\hline Americorophium stimpsoni & Arthropoda: Amphipoda & & & & & 100 & & & \\
\hline Pygospio elegans & Annelida: Polychaeta & & & & & 99 & & & \\
\hline Eogammarus confervicolus Complex & Arthropoda: Amphipoda & & & & & 99 & & & \\
\hline Americorophium spinicorne & Arthropoda: Amphipoda & & & & & 98 & & & \\
\hline Hobsonia florida & Annelida: Polychaeta & & & & & 97 & & & \\
\hline Gnorimosphaeroma insulare & Arthropoda: Isopoda & & & & & 97 & & & \\
\hline Potamopyrgus antipodarum & Mollusca: Gastropoda & & & & & 93 & & & \\
\hline Cryptomya californica & Mollusca: Bivalvia & & & & & 91 & & & \\
\hline Pseudopolydora kempi & Annelida: Polychaeta & & & & & 91 & & & \\
\hline Neanthes limnicola & Annelida: Polychaeta & & & & & 87 & & & \\
\hline Gnorimosphaeroma oregonense & Arthropoda: Isopoda & & & & & 83 & & & \\
\hline Macoma balthica & Mollusca: Bivalvia & & & & & 82 & & & \\
\hline Capitella capitata Complex & Annelida: Polychaeta & & & & & 82 & & & \\
\hline Eohaustorius estuarius & Arthropoda: Amphipoda & & & & & & 90 & & \\
\hline Corbula amurensis & Mollusca: Bivalvia & & & & & & & 99 & \\
\hline Marenzelleria viridis & Annelida: Polychaeta & & & & & & & 98 & \\
\hline Insecta & Arthropoda: Insecta & & & & & & & & 99 \\
\hline Boccardiella ligerica & Annelida: Polychaeta & & & & & & & & 93 \\
\hline Corbicula fluminea & Mollusca: Bivalvia & & & & & & & & 92 \\
\hline Chironomidae & Arthropoda: Chironomidae & & & & & & & & 86 \\
\hline Americorophium salmonis & Arthropoda: Amphipoda & & & & & & & & 29 \\
\hline
\end{tabular}


Table 6. Percentage of temporal replicates from single sites that clustered adjacent to each other on the dendrogram

\begin{tabular}{|lcc|}
\hline Station & Samples & $\begin{array}{c}\text { Adjacent } \\
\text { Samples (\%) }\end{array}$ \\
\hline Stations in Puget Sound, State of Washington & \\
\hline PST-03 & 18 & 100.0 \\
\hline PST-04 & 18 & 100.0 \\
\hline PST-13R & 18 & 100.0 \\
\hline PST-21 & 18 & 100.0 \\
\hline PST-29 & 18 & 100.0 \\
\hline PST-34 & 18 & 94.4 \\
\hline PST-38 & 18 & 88.9 \\
\hline PST-40 & 17 & 100.0 \\
\hline PST-44 & 17 & 100.0 \\
\hline PST-49 & 18 & 94.4 \\
\hline Stations in San Francisco Bay, State of California & \\
\hline SFE-BB15 & 10 & 40.0 \\
\hline SFE-BC21 & 10 & 100.0 \\
\hline SFE-BC60 & 10 & 50.0 \\
\hline SFE-BD15 & 11 & 54.5 \\
\hline SFE-BD41 & 13 & 46.2 \\
\hline
\end{tabular}

Although there was a high degree of similarity within the 8 assemblages identified, it is not clear that these are the only assemblages occurring on the west coast. The sampling programs on which our analyses were based were extensive, but they all had probability-based sampling designs. As such, spatially rare habitats, such as the shallow margins of estuaries, were not well represented. In addition, the cluster analysis was conducted on a coastwide data set, potentially masking microhabitat assemblages that might be more apparent in large data sets within a single estuary. However, our large, coastwide data set allows identification of the major assemblages of the west coast and the principal factors that structure them.

The State of California developed habitat specific methods to assess benthic condition based on the habitat factors structuring the major assemblages that were identified in this study. Benthic assessment tools were developed in 2 California habitats where sufficient data for index development were available (Ranasinghe et al. 2009), and used to assess sediment quality in combination with sediment contaminants and sediment toxicity using a triad approach (Bay and Weisberg 2010). Our findings suggest that some assemblages span several states and California benthic assessment approaches may, therefore, also be applicable in other states. Conversely, developing habitat specific benthic assessment tools unconstrained by state borders provides additional data for tool development, likely resulting in more robust assessment tools that will also provide opportunities for multistate regional assessments on uniform scales.

\section{REFERENCES}

Bald J, Borja A, Muxika I, Franco J, Valencia V. 2005. Assessing reference conditions and physico-chemical status according to the European Water Framework Directive: A case-study from the Basque Country (Northern Spain). Mar Pollut Bull 50:1508-1522.

Bay SM, Weisberg SB. 2012. Framework for interpreting sediment quality triad data. Integr Environ Assess Manag 8:589-596.

Bergen M, Weisberg SB, Smith RW, Cadien DB, Dalkey A, Montagne DE, Stull JK, Velarde RG, Ranasinghe JA. 2001. Relationship between depth, sediment, latitude, and the structure of benthic infaunal assemblages on the mainland shelf of southern California. Mar Biol 138:637-647.

Boesch DF. 1973. Classification and community structure of macrobenthos in the Hampton Roads area, Virginia. Mar Biol 21:226-244.

Boesch DF. 1977. A new look at the zonation of benthos along the estuarine gradient. In: Coull BC, editor. Ecology of marine benthos. Columbia (SC): University of South Carolina Press. p 245-266.

Bradfield GE, Kenkel NC. 1987. Nonlinear ordination using shortest path adjustment of ecological distances. Ecology 68:750-753.

Bray JR, Curtis JT. 1957. An ordination of the upland forest communities of southern Wisconsin. Ecol Monogr 27:325-349.

Briggs JC. 1974. Marine zoogeography. New York (NY): McGraw-Hill. 475 p.

Briggs JC. 1995. Global biogeography. New York (NY): Elsevier. 452 p.

Brinkhurst RO. 1982. British and other marine and estuarine oligochaetes. New York (NY): Cambridge University Press. 126 p.

Clarke KR, Warwick RM. 2001. Change in marine communities: An approach to statistical analysis and interpretation. Plymouth, UK: Primer-E Ltd.

Clifford HT, Stephenson W. 1975. An introduction to numerical classification. New York (NY): Academic Press.

Cloern JE, Nichols FH. 1985. Time scales and mechanisms of estuarine variability, a synthesis from studies of San Francisco Bay. Hydrobiologia 129:229237.

Conomos TJ, Smith RE, Gartner JW. 1985. Environmental setting of San Francisco Bay. Hydrobiologia 129:1-12.

Cross JN, Allen LG. 1993. Chapter 9. Fishes. In: Dailey MD, Reish DJ, Anderson JW, editors. Ecology of the Southern California Bight. Berkeley and Los Angeles (CA): University of California Press. p 459-540.

[EC] European Commission. 2000. Directive 2000/60/EC of the European Parliament and of the Council establishing a framework for the Community action in the field of water policy.

Gibson GR, Bowman ML, Gerritsen J, Snyder BD. 2000. Estuarine and coastal marine waters: Bioassessment and biocriteria technical guidance. EPA 822-B00-024. Washington (DC): US Environmental Protection Agency, Office of Water.

Hughes RM, Larsen DP, Omernik JM. 1986. Regional reference sites: A method for assessing stream potentials. Environ Manag 10:629-635.

Hyland JL, Balthis WL, Posey MH, Hackney CT, Alphin TD. 2004. The soft-bottom macrobenthos of North Carolina estuaries. Estuaries 27:501-514.

Jackson SK, Davis WS. 1994. Meeting the goal of biological integrity in water resource programs in the US Environmental Protection Agency. J North Am Benthol Soc 13:592-597.

Lance GH, Williams WT. 1967. A general theory of classificatory sorting strategies. I. Hierarchical systems. Comput J 9:373-380.

Llansó RJ, Aasen S, Welch KI. 1998. Marine sediment monitoring program - II. Distribution and structure of benthic communities in Puget Sound, 19891993. Publication No. 98-328. Olympia (WA): Washington State Department of Ecology.

Llansó RJ, Scott LC, Dauer DM, Hyland JL, Russell DE. 2002. An estuarine benthic index of biotic integrity for the Mid-Atlantic region of the United States. I. Classification of assemblages and habitat definition. Estuaries 25:12191230.

Long ER, Dutch M, Aasen S, Welch KI, Hameedi MJ. 2003. Chemical contamination, acute toxicity in laboratory tests, and benthic impacts in sediments of Puget Sound: A summary of results of the joint 1997-1999 Ecology/NOAA survey. Publication No.03-03-049. Olympia (WA): Washington State Department of Ecology. 
Long ER, MacDonald DD, Smith SL, Calder FD. 1995. Incidence of adverse biological effects within ranges of chemical concentrations in marine and estuarine sediments. Environ Manag 19:81-97.

Murawski SA. 2007. Ten myths concerning ecosystem approaches to marine resource management. Mar Policy 31:681-690.

[NOAA] National Oceanic and Atmospheric Administration. 1975. The coastline of the United States. NOAA/PA 71046 (Rev. 1975). Washington (DC): National Oceanic and Atmospheric Administration.

Nichols FH, Thompson JK. 1985. Time scales of change in the San Francisco Bay benthos. Hydrobiologia 129:121-138.

Orloci L. 1975. Multivariate analysis in vegetation research. The Hague, Netherlands: Dr. W Junk.

Ranasinghe JA, Montagne DE, Smith RW, Mikel TK, Weisberg SB, Cadien DB, Velarde RG, Dalkey A. 2003. Southern California Bight 1998 Regional Monitoring Program: VII. Benthic macrofauna. Technical Report 382. Westminster (CA): Southern California Coastal Water Research Project.

Ranasinghe JA, Barnett AM, Schiff KC, Montagne DE, Brantley C, Beegan C, Cadien DB, Cash C, Deets GB, Diener DR, Mikel TK, Smith RW, Velarde RG, Watts SD, Weisberg SB. 2007. Southern California Bight 2003 Regional Monitoring Program: III. Benthic macrofauna. Technical Report 529. Costa Mesa (CA): Southern California Coastal Water Research Project.

Ranasinghe JA, Weisberg SB, Smith RW, Montagne DE, Thompson B, Oakden JM, Huff DD, Cadien DB, Velarde RG, Ritter KJ. 2009. Calibration and evaluation of five indicators of benthic community condition in two California bay and estuary habitats. Mar Pollut Bull 59:5-13.

Schiff KC. 2000. Sediment chemistry on the mainland shelf of the Southern California Bight. Mar Pollut Bull 40:268-276.

Schiff KC, Maruya K, Christenson K. 2006. Southern California Bight 2003 Regional Monitoring Program Volume II: Sediment Chemistry. Westminster (CA): Southern California Coastal Water Research Project.

Smith RW. 1976. Numerical analysis of ecological survey data [PhD Thesis]. Los Angeles (CA): University of Southern California.

Smith RW, Bernstein BB, Cimberg RL. 1988. Community-environmental relationships in the benthos: Applications of multivariate analytical techniques. In:
Soule DF, Kleppel GS, editors. Marine organisms as indicators. New York (NY) Springer-Verlag. p 247-326.

Southern California Association of Marine Invertebrate Taxonomists. 2001. A taxonomic listing of soft bottom macro- and megainvertebrates from infaunal \& epibenthic programs in the Southern California Bight, Edition 4. San Pedro (CA): Southern California Association of Marine Invertebrate Taxonomists.

Thompson B, Lowe S, Kellogg M. 2000. Results of the Benthic pilot study 1994 1997. Part 1. Macrobenthic assemblages of the San Francisco Bay-Delta and their responses to abiotic factors. Report No 39. Richmond (CA): San Francisco Estuary Institute.

[US EPA] US Environmental Protection Agency. 1991. Policy on the use of biological assessments and criteria in the water quality program. Washington (DC) United States Environmental Protection Agency.

[USEPA] US Environmental Protection Agency. 2004. National Coastal Condition Report II. Washington DC: USEPA. EPA-620/R-03/002.

[UNESCO] United Nations Educational, Scientific, and Cultural Organization. 2006. A handbook for measuring the progress and outcomes of integrated coastal and ocean management. IOC Manual and Guides, No. 46; ICAM Dossier No. Paris: UNESCO.

Van Dolah RF, Hyland JL, Holland AF, Rosen JS, Snoots TR. 1999. A benthic index of biological integrity for assessing habitat quality in estuaries of the southeastern USA. Mar Environ Res 48:269-283.

Vidal DE, Bay SM. 2005. Comparative sediment quality guideline performance for predicting sediment toxicity in southern California, USA. Environ Toxicol Chem 24:3173-3182.

Weisberg SB, Ranasinghe JA, Schaffner LC, Diaz RJ, Dauer DM, Frithsen JB. 1997. An estuarine benthic index of biotic integrity (B-IBI) for Chesapeake Bay. Estuaries 20:149-158.

Whittaker RH. 1978. Classification of plant communities. The Hague, Netherlands: Dr. W. Junk, Publishers.

Williamson $\mathrm{MH}$. 1978. The ordination of incidence data. J Ecol 66:911920. 